\title{
A DRÁMAPEDAGÓGIA HATÁSA A TANÁRI KOMPETENCIÁK ALAKULÁSÁRA
}

\author{
Szerző: \\ Varga-Csikász Csenge (Drs) \\ Eszterházy Károly Egyetem
}

Szerző e-mail címe:

varga.csikasz.csenge@gmail.com

\author{
Lektorok: \\ Szabóné Balogh Ágota (PhD) \\ Gál Ferenc Egyetem \\ Kovács-veréb Lilla (Drs) \\ Károli Gáspár Református Egyetem \\ ...és további két anonim lektor
}

\begin{abstract}
Absztrakt
A drámapedagógia Magyarországon már az 1970-es évektől jelen van, ez idő alatt az oktatásban betöltött szerepe sokat változott. A dráma eszközeinek fiatalokra gyakorolt személyiségfejlesztő hatásai már jól ismertek, de az általános tanárképzésben még mindig nem foglalta el méltó helyét, pedig ez a gyakorlatorientált módszer a pedagóguskompetenciákat is pozitívan formálja. A tanulmányban közölt kutatási terv a következő kérdésre fókuszál: hogyan segíthet a drámapedagógia a pedagógussá válás folyamatában?
\end{abstract}

Kulcsszavak: drámapedagógia, kutatási terv, pedagóguskutatás

Diszciplina: pedagógia

\begin{abstract}
THE EFFECT OF DRAMA PEDAGOGY ON THE DEVELOPMENT OF TEACHER COMPETENCIES

Drama pedagogy has been present in Hungary since the 1970s, during this time, its role in education has changed a lot. The personality development effects of drama tools on young people are already well known but hasn't occupied a worthy place in general teacher education yet, although this practice-oriented method also positively shapes teacher competencies. In this study a research plan focuses on the following question: how can drama pedagogy help in the process of becoming a teacher?
\end{abstract}

Keywords: drama pedagogy, project, development of pedagogue

Discipline: pedagogy

Varga-Csikász Csenge (2020): A drámapedagógia hatása a tanári kompetenciák alakulására. OxIPO - interdiszciplináris tudományos folyóirat, 2020/3, 55-72. doi: 10.35405/OXIPO.2020.3.55 
Magyarországra az 1970-es években Mezei Éva és Debreczeni Tibor külföldi tapasztalatainak köszönhetően került a drámapedagógia. A módszer gyakorlattal kapcsolatos szakértelmét Mezei Éva Birminghamből, Debreczeni Tibor pedig Prágából hazatérve osztotta meg a szakmabeliekkel, gyermekszínjátszással foglalkozókkal. Később pedagógiai kísérletekben értintetté vált a téma - Gáspár László és Zsolnay József munkásságát kiemelve , de Gabnai Katalin neve is közismertté vált a drámajátékokkal kapcsolatban.

1988-ban alakult meg a Magyar Drámapedagógiai Társaság, melynek tagjai nagy szerepet játszottak a drámapedagógiai módszerek terjesztésében, és a kilenctagú vezetőség jelenleg is - Kaposi László vezetésével - képzésekkel, szakmai napokkal, versenyekkel igyekszenek színesíteni a nevelési programok palettáját.

A drámapedagógia magyarországi történetében fontos esemény volt David Davis 1991-ben Fóton tartott kurzusa. A dráma professzorának célja a módszer hazai önállósodásának elősegítése volt.

A témában ma, Cziboly Ádámmal együtt is kutató Bethlenfalvy Ádám írására hivatkozva, az angol drámapedagógia történetéből több úttörő nevét szükséges kiemelnünk: Peter Slade, Gavin Bolton és Jonothan Neelands személye mellett persze Dorothy Heathcote munkásságának említése is elengedhetetlen az angol drámapedagógiában (Bethlenfaly, 2005). Az angolszász dráma kapcsán két kategória, a
Drama in Education (DIE) és a Theatre in Education (TIE) ismert.

A DIE célja: problémák drámán keresztüli megértése; a második a színházról való tanulás. A tanítási dráma Dorothy Heathcote nevéhez kötődik, követői is rá hivatkoznak a fogalmat használva, de Gavin Bolton volt, aki osztályozta dramatikus tevékenységformákat. A felosztásban a tanítási - vagy az úgynevezett „komplex” dráma - volt a „D” típus. Ez utóbbi terjed el a magyar drámapedagógusok körében is. A komplex drámában a játszók egy „mintha” világba kerülnek. Erről Jonothan Neelands (2013, 8. o.) így ír:

- „Úgy cselekszem »mintha« valaki más lennék.

- Úgy cselekszem »mintha« ebben a helyzetben lennék.

- Úgy cselekszem »mintha« ez a tárgy valami más lenne."

Az résztvevők közösen élik meg az adott témán belül feldolgozni kívánt problémát.

A második típus, a TIE napjainkban egyre inkább kikerülni látszik az angol oktatásból: az úgynevezett ,soft skills”-ek helyére egyre inkább a megélhetést szolgáló tárgyak kerülnek be az iskolákba. (Bethlenfalvy, 2017). A Magyar Drámapedagógiai Társaság által 1993 óta minden évben két alkalommal hirdetik meg a 120 órás akkreditált drámapedagógus képzést, melyben kiemelt szerepet kap a tanítási 
dráma, a kurzus sikeres teljesítését egy ilyen foglalkozás megtartásához kötik.

A drámapedagógia útjának egy részébe beletekintve jogosan érezhetnénk, hogy mára már a magyar oktatásban és nevelésben sikeresen meghonosodott. A drámával foglalkozó szakemberek hisznek a módszer hatásosságában, napi szinten tapasztalják annak eredményességét, de a gyökeres változáshoz, áttöréshez a drámapedagógia általános tanárképzésbe történő bevezetése lenne szükséges.

Az iskolákban, az általános gyakorlatban még mindig nem vált gyakorlatiassá a módszer használata. Szabó Zsófia 2015ben végzett kutatása kimutatta, hogy a drámás képzettségű oktatók töredéke használja tantárgyi keretek között a szaktudását (Szabó, 2016).

A módszer aktualitása, használhatósága az oktatásban (személyiségfejlesztés, kapcsolatteremtés elősegítése) kiemelendő. Az Y generációnak az első nemzedék, amely gyermekkorától kezdve találkozhatott olyan elektronikai eszközökkel, és a világhálón való időtöltéssel, ami a mindennapi tevékenységeink, munkáink részévé váltak (Szőke-Milinte, 2019). Ezért szükséges az iskola rendszerén keresztül a lexikai tudás megszerzése mellett - a drámapedagógiát, és a hozzá hasonló módszereket tudatosan beépíteni a diákok hétköznapjaiba.

Az újabb generációkat tanító szakemberek képzése már diákkorban is elkezdődik, hiszen a pedagógussá válás folyamata nem az egyetemre lépéssel indul el. A tanári pályára lépést elősegítik azok a tapasztalatok, amit diákként az osztálytársak vagy kisebbek tanításában átélünk, vezetői feladatokban vállalunk, színpadhoz való kiállásunkban, előadásunkban vagy más múvészeti tevékenységben megtapasztalunk (Dudás, 1984, 2013, Komlósi, Dudás és Vastagh, 1987).

\section{A DRÁMAPEDAGÓGIA ALAKULÁSA MAGYAR- ORSZÁGON}

Az 1973-ban Mezei Évának és Debreczeni Tibornak a Pécsen megrendezett Országos Diákszínjátszó Fesztivál nyújtott lehetőséget arra, hogy a szakmabelieknek és a nagyközönségnek is átadhassák a külföldön szerzett ismereteiket. Ezen az alkalmon számolnak be először a fentebb említett birminghami és prágai tapasztalatokról. Mindketten látták, hogy a gyermekszínjátszás mellett az iskolai oktatásban is alkalmazható lenne a drámapedagógia nyújtotta eszköztár. De ezt megelőzően először a gyermek- és diákaszínjátszó közösségek gyakorlatába és a játszóházi tevékenységekbe emelték át a módszer elemeit. Mezei és Debreczeni is a hétköznapi oktatás megújítását látta a tanintézményekben való beemelés gondolatában (Tölgyessy, 2011). A drámapedagógia több az egyszerű utánzásnál, mely „során a jelentésnek mindössze egyetlen dimenzióját adja: a denotatív vagy tárgyi jelentést. Ahhoz, hogy a cselekvés drámai erővel bírjon, más jelentéstartalmaknak 
kell előtérbe kerülniük. (A drámatanmenetek többsége sajnos erőteljesen épít az utánzásra ezen belül pedig nem ritkán az érzelmek imitációját várja el!) Ezt pedig két egymással szembeállítható tényező határozza meg: a személyes, egyedi és az általános érvényü jelentés." (Bolton, 1996, 2. o.). A ma drámát oktatók, tanítási drámát használó pedagógusok ezen felismeréseknek és oktatási anyagok létrehozásának hála, olyan alapvető ismeretekkel, fogalomtárral rendelkezhetnek, amivel korábban nem.

A dráma egyik ilyen technikai fogásáról, a konvenciókról, Dorothy Heathcote a következőképpen ír: „A konvenciók (...) speciális módokon aknázzák ki a jel és jelentés viszonyát: legtöbbjük megváltoztatja a szereppel való kapcsolatteremtés és a »közvetlen idő« (immediate time) működésének módját, (...) lelassítja az időt, valamint saját gondolkodásuk és a döntések feletti hatalomhoz juttatja az osztályokat." (Heathcote, 2013, 123. o.). A drámapedagógia iskolák falain belüli terjeszkedéséhez Zsolnai József 1971-es nyelvi, irodalmi és kommunikációs programja is hozzájárult, azzal hogy a program tervezetébe bekerültek a dramatikus eljárások is (Eck, 2015). A már említett drámapedagógus, Gabnai Katalin, aki - bár Mezezinél és Debreczeninél fiatalabb - a módszer honosítóinak oszlopos tagja, ma is élharcosa a drámapedagógia küzdelmeinek. Többször megfogalmazta munkássága során a szakos tanárképzés szükségességét, de számtalan elutasítást kapott az ötlete. Egy 2019-es szakmai előadáson idézték egy levelének szavait, amiben úgy fogalmazott, hogy amíg a drámapedagógiai nincs az általános tanári és nevelési képzésben, addig a törekvések csak önálló „partizánakciók”. (Kinyílt az aranykapu? Színházi nevelés és a rendszerváltás, 2019). A drámapedagógia követelményrendszerének kidolgozásában is részt vállalt, mely munka a dramatikus nevelési program 1972-1982-ig néven található meg (Papp és Trencsényi, 1984). Végül a '90-es években a Színházés Filmművészeti Egyetemen elindulnak a szakirányú továbbképzések, melyekben Gabnai Katalin vezető szerepet játszik. Így alakult meg az első drámapedagógiai képzés, ami mellett 1993-ban Zsámbékon is kezdetét veszi egy kurzus, Gabnai és Móka János szervezésében.

1995-ben - amikor a Nemzeti Alaptantervbe is bekerül a mûvészetek műveltségterület - az iskolák is tárt kapukkal várják a tánc és dráma néven ismerté vált tárgyat (Tölgyessy, 2011).

2003-ban a dráma és tánc névre módosult műveltség(rész)te-rület óraszámai nem erősödtek tovább, pedig hogy „mára a tartalmi szabályozók tekintetében szinte a többivel teljesen egyenrangú tantárgy lett a Dráma és tánc, létezik dráma érettségi, OKTV, felmenő rendszerű művészeti versenyek, kiépültek a színjátékos alapfokú múvészeti iskolák és léteznek egyetemi képzések, sőt formálódóban van egy akadémiai bizottság is a témában" (Kaposi, 2015, 2. o.). 
A tantárgy a 2000-es évektől önálló óraszámmal van jelen az 5-6. és gimnáziumi 9-10. osztályban. A helyi tantervben és gyakorlatban a tárgyon belüli részterületek (dráma, népi kultúra, bábjáték, néptánc) megismerésére kéthetente egy óra adott. Visszalépés volt a 2010-es év a dráma és tánc érettségi vizsgát illetően, ugyanis 2005-től kétszintű-, 2010 őszétől középszintű vizsga tehetô le a tárgyból. (Tölgyessy, 2011).

A dráma fejlődése, iskolába és felsőoktatásba való bekerülése ellenére a szakmabeliek folyamatos küzdelmekről adnak tájékoztatást. A bevezetőben már említett kutatás (Szabó, 2016) amellett, hogy bemutatta az olyan drámás végzettségűek számát, akik tantárgyi keretek között is használják drámás szaktudásukat, más információkkal is szolgál. Az általános- és középiskolai drámaoktatásban milyen arányban találhatóak meg a drámás végzettségű pedagógusok. A statisztikai adatok a különböző megyék közti különbségeket is jól kimutatják - melyben Pest megye kiemelkedő mint kulturális központ -, drámatanításban például BorsodAbaúj-Zemplén és Jász-Nagykun-Szolnok jó adatokat mutat a nagyobb népsűrűségű és területű megyék melletti hátrányban is. Tolna, Baranya, Heves és Nógrád megyében kevesebb aktivitást vélhetünk felfedezni.

Az elektronikai eszközök megjelenésével az iskolai tevékenységformák is kezdtet átalakulni, és talán napjainkban, 2020ban egy világjárvány betoppanásával és az online oktatásba való kényszerüléssel nem kell bemutatni, hogy milyen digitális alternatívákat használhatunk a tanulás és tanítás érdekében Az online funkciókkal élve személyes kapcsolataink, a jelen világban való létezésünk is átalakult: bármikor bárhol elérhetővé vált az ember, a tanár, a diák és a tananyag is. Az világhálón a drámapedagógiai tevékenységek is megállják a helyüket, megalakult a Dráma akciócsoport, melynek célja „hogy keressük, kutassuk, felfedezzük a drámapedagógia alkalmazási lehetőségeit a tantermen kívüli digitális munkarendben. Hiszünk abban, hogy ez a nem vágyott helyzet mindanynyiunk számára lehetőség is, amelyben megmutathatjuk a drámapedagógia erejét és a drámapedagógusok kreativitását, amely nem ismer lehetetlent, és amelynek az online tér sem szabhat gátat" (Magyar Drámapedagógiai Társaság, 2020).

Ha általánosságban beszélünk az internethasználatról, annak az ifjú generációkra gyakorolt pozitív és negatív oldalait is látnunk kell, hiszen nem zárkózhatunk el a fejlődés eme formájától sem (már nem is tudunk): az elektronikai eszközök tudatosan történő használata tanulható és tanulandó feladatunk. Az X generáció idejében a munka területén már használatosak voltak az elektronikai eszközök, de az Y generáció az első olyan nemzedék, akik életét gyermekkortól fogva a „digitális kütyük" és a világhálón való időtöltés szövi és formálja át (Szőke-Milinte, 2019). A ,digitális detox” kifejezése nem sokkal az okostelefonok megjelenését követően 
jelent meg. A fogalmat Catherine Price azonos címú könyve alapján ismerhetjük, amely információval szolgálhat azoknak, akiknek a valódi élmények megélése, befogadása a telefonja nélkül már nehézséget okoz. „A digitális nemzedék gyűjtőfogalom. Vonatkozik mindazokra a generációkra, akik igen korai életszakaszban találkoztak a digitális technológiával, és igen korai életszakaszban annak felhasználóivá is váltak, tehát alapjában határozta meg a szocializációjukat a digitalizáció. Leginkább az Y, Z és az alfa generációkról beszélünk, amikor a digitális nemzedéket említjük.” (Szőke-Milinte 2019, 131. o.). Az oktatási reformok gondolata e két generációt, a $Z$ és az alfa nemzedéket érinti leginkább. A közösségi kapcsolatok kialakítása, megtartása és folyamatos ápolása kiemelten fontos az emberi életben - ennek hiányát napjainkban is átélhetjük. Amellett, hogy megtanuljuk, megtanítjuk hogyan töltsük el helyesen az időnket az online felületeken, arányosan fontossá válik annak az átadása, hogyan töltsük fel minőségi idővel, valódi értékekkel személyes kapcsolatainkat.

A XX. században reformpedagógiák nevelési elveiben megjelent az a gondolat, hogy a pedagógiai tevékenységeket a szocializációs elvárásokkal összhangba állítsák. Nem lehet meglepő tehát a felvetés a XXI. században sem, miszerint a nevelési módszereket a társadalmi igényekkel összhangba kell állítani. „Azok a gondolatok, melyekből a drámapedagógia szemléletmódja táplálkozik, nem újkeletűek. Már az ókori Görögországban jellemző volt az »akadémia« (kiemelkedett ezek közül Platón iskolája), ahol a híres filozófus természeti környezetben beszélgetett, vitatkozott a köréje sereglett fiatalokkal." (Pukánszky és Németh, 1996, 53. o.). Hasonló hatással lehetett „Nietzsche életfilozófiája, Spencer pozitivista etikai nevelésfelfogása, Darwin fejlődéselmélete, Galton genetikai kutatásai, Owen gyermeki jogokról vallott véleménye, Malthus népességelmélete, ill. a korszak szociális- ifjúsági és emancipációs nőmozgalmainak jellegzetes gondolatai” a reformpedagógiai áramlatok iskolamodelljeire, mint a globális technikai változások jelenünkre (Pinczésné, 2003. 9. o.). A reformpedagógiák hagyományos pedagógus-diák kapcsolatot megbontó törekvései saját korukban ugyanolyan elképzelhetetlenek voltak, mint pár évtizeddel ezelőtt az, hogy országokat áthidalva, a képernyőn keresztül, telefon és laptop segítségével tanuljunk nyelveket egymástól több száz, vagy ezer kilométerre. A lehetőségek végtelenek, de ezek erdejében mennyire tudjuk megőrizni a személyes jelenlétet?

A reformpedagógiák többsége a harmóniára, a közösségi lét és a gyermek személyiségének egységére, az egyensúly megtalálására fókuszál. S. Lorain Hull $S_{z i^{-}}$ nésżmesterség mindenkinek című könyvében Lee Strasberg módszeréről ír, aki Sztanyiszlavszkij technikáit tovább fejlesztve olyan gyakorlatokat hozott létre, melyek segítségével megtanulhatjuk, hogyan bánjunk az érzelmeinkkel. A gyakorlatokat 
ajánlják személyiségfejlesztő csoportoknak, drámakurzusok résztvevőinek, drámát oktatóknak is. A drámatanárok által közvetített gondolatokat már Maria Montessori pedagógiai metodikájában is fellelhetjük: „A gyerekek képesek figyelemmegosztásra, reakció idejük gyorsabb, de nehezebben összpontosítanak, és csak intenzív ingerekre reagálnak. Hagyományos módszertannal nehéz kiváltani motivációt. (...) Jó, ha mozoghatnak, kommunikálhatnak egymással.” (Eck, 2015, 5. o.). A XXI. században - IKT eszközök, a teljesítményorientált nevelési elvek és fel-fel törekvő alternatív pedagógiák között - is fontos, hogy megtaláljuk az oktatási módszerek hálózatában az arany középutat.

\section{A PEDAGÓgUSSÁ VÁLÁS FOLYAMATA A DRÁMA- PEDAGÓGIA TÜKRÉBEN}

„Tudjuk, hogy a gyerekek tanulása jórészt játékban valósul meg. A mai közgondolkodás ettől eltér. Kritikusai szerint iskoláinkat még mindig herbarti terek uralják. Gyermekeinket 6 éves kortól kényszerítjük iskolapadba, legalább tíz évig napi 6-7 órában zárjuk őket a tanterem, a szűk tér rabságába.” (Eck, 2015, 5. o.). Talán maga az a teljesítményorientált világnézet is közre játszik abban, ami napjainkban az oktatásban is problémaként merül fel - mind a felsőoktatási, mind a közép- és általános iskolai tananyagbeli terheltséget illetően. Ha nem is értünk egyet azzal, hogy korábban kevesebbet kellett volna tanulnia bárkinek, a Z és alfa generáció befogadóképessége megváltozott.

A drámapedagógia elterjedtségének, használhatóságának kérdése - ezen tények függvényében - joggal merül fel az azt alkalmazó szakemberekben: nagy szükség van arra, hogy az iskolában olyan ventilálási, stresszlevezetési lehetőségeket kínálhassunk fel az újabb generációnak, amikben fel tudják oldani azt a rengeteg (például vizuális) ingert, ami percről percre éri őket a média (köztük: okostelefonok, órástévék, utcai kivetítők) hatásának tömkelege által is. Lehet, hogy - mindezen impresszióknak is köszönhetően - most jött el az ideje annak, hogy a drámapedagógia kiteljesedjen, hiszen szükség van az emberi kapcsolatépítő, közösségformáló és személyiségformáló erejére. Ehhez viszont olyan pedagógusokra lenne szükség, akik alkalmazzák és terjesztik ezt a módszert, újabb és újabb drámás gyakorlatokat ismerő, önazonos utánpótlást nevelve ezzel.

\section{A SZEREPRŐL ÁLTALÁNOSSÁGBAN}

„Az a kép, amely a leginkább tükrözi a tanításról alkotott nézeteimet, a következő: az iskola egy színház, és ebben a színházban a tanár a dramaturg, következésképpen ő dönti el, hogyan alkalmaz a színpadra valamit, hogy abból előadás lehessen. A tanulók statiszták, akik a tanulással igazi színészekké válhatnak." (Dudás, 2013, 65. o.). A drámapedagógia és a színházi nevelés eszköztárát vizsgálva 
tudhatjuk, hogy a módszer az érzelmi intelligencia, a helyes erkölcsi magatartás és a személyiség fejlesztésére is pozitiv hatást gyakorol. A fiatalok formálása mellett a technikát alkalmazó pedagógusokat is optimizmussal tölti fel.

A tanár- és diákszerepekbe - ugyanúgy, mint más szociális szerepeinkbe is - belenövünk, beleszületünk. Az, hogy milyen szerepeket vállalunk a világ színpadán, nem mindig megválasztható. A szerencsésebbek saját életükben a föszerepet játszhatják, és a darabjuk rendezői állását is betöltve ezzel önmagukat vállalják fel. Adódnak olyan életszerepek, amik örökre szólnak, nem tudunk kilépni belőlük. Amikor valaki szülővé válik, akkor megváltoztathatatlanul szülő lesz. „Mit jelent apának, főnöknek, beosztottnak, mit jelent kamasznak, s mit jelent gyereknek lenni?" - teszi fel a kérdést Gabnai Katalin drámapedagógus (Gabnai, 1999, 181. o.). Az iskolába lépve 6-7 évesen azt viszszük magunkkal, amit otthonról kaptunk, a drámajátékok során pedig ugyanezzel a csomaggal dolgozhatunk. A szerepben való játék arra is lehetőséget ad, hogy megjelenítsük a legjobb diákot, miközben a legrosszabbnak érezzük magunkat, s ezért talán mások is annak tartanak. $\mathrm{Ha}$ jól alakítunk, a szerepből kilépve is megélhetjük az ott tapasztalt pozitívumokat: az iskolapadban újra eszünkbe juthatnak jó tanuló személyiségvonásai, és a valóságban is megpróbálhatjuk átélni azt. Szerepben a szegény lehet gazdag, a gazdag pedig szegény - szembesülhetünk az anyagiaktól független barátságokkal és értékekkel, vagy éppen a pénz okozta elszigeteltséggel.

A drámapedagógia és a színházi nevelés eszközei ilyen „mintha” helyzetet teremtve lehetőséget adnak olyan dolgok utánzására, amikkel már találkoztunk, és olyanokra is, amikkel még nem, vagy nem is fogunk másképp - ezek megjelenítésének csak a fantázia szabhat határt. Önmagunkat más perspektívából ismerhetjük meg, újragondolhatunk bizonyos helyzeteket, szerepeket cserélhetünk, hogy megértsünk és megoldjunk konfliktusokat. „Bevallott célunk tehát a szociális szerepviselkedés készségtárának, kelléktárának fejlesztése is." (Gabnai, 1999, 181. o.). Amikor egy pedagógus amellett dönt, hogy a dráma eszközeit használja - akár konfliktusmegoldás, akár beszédfejlesztés, akár egy tananyag megértése a célja vele - lehetőséget ad, arra, hogy a kreativitásra, és ezzel együtt a gyermek személyiségére kerüljön a fókusz - így segítve elő a jövőbeli társadalmi és szociális szerepvállalását is (Varga-Csikász, 2018).

\section{A TANÁRI SZEREP ÉS A DRÁMAPEDAGÓGIA}

Az emberi életben a minták, és azok követése vagy elhagyása kifejezetten jelentőségteljes, főleg azokban az időszakokban, amikor változáson megyünk keresztül. Ezek a szakaszok a pedagógussá válás folyamatában is megjelennek, és nemcsak akkor, amikor már valaki betöltötte ezt a 
munkakört - jóval előbbi élményeket kell keresnünk. „Minden kezdet nehéz mondja a magyar és a német egyaránt. És valóban: a pedagógussá válás folyamatában minden egyes szakasz újabb kihívásokat, nehézségeket és lehetőségeket jelent. A német szakirodalomban nemcsak a pedagógussá válás folyamatának három szakasza, a hallgatói, a gyakornoki és a tanári szakasz kap különös hangsúlyt. Egyre többen kutatják ezen szakaszok kezdetét is, amire a német nyelvben külön szó van: az elkezdés időszaka” (Bikics, 2013).

Sok pedagógusjelölt a tanári gyakorlatának megkezdése pillanatában ismeri fel azt - és remélhetően felismeri -, hogy a korábbi tanárszerepek, amelyek példaként jelentek meg a diákéveiben, és a saját szerepvállalásaik milyen befolyással lehetnek tanári megnyilvánulásaikra. A pedagógussá válás folyamata már elkezdődhetett „a korábbi kortárscsoportokban vállalt vezetői feladatok, az osztálytársak és/vagy kisebb gyerekek tanítása, színpadhoz kapcsolódó múvészeti csoportokban végzett tevékenységgel (...). Az ilyen háttérrel rendelkező tanárjelöltek eredményesebben oldották meg a kapcsolatteremtési, kommunikációs képességek múködését igénylő feladatokat (Dudás, 1984; Komlósi, T. Dudás, Vastagh, 1987)." (Dudás, 2013). A személyes és iskolai élmény tehát már azelőtt formálja a pedagóguspályára lépő hallgatót, mielőtt még a hivatás iránti elköteleződés csírája napfényhez és vízhez juthatna. Ebből látható, hogy a gyermeknek, mint a jövő pedagó- gusának, hogyan válik hasznává az a szerepskála, amiben a drámapedagógiai tevékenységben kipróbálhatná magát.

A hallgatók más és más tudásanyaggal érkeznek az egyetemekre, hiszen különböző iskolákban, különböző mintákat sajátítottak el. Az egységesen meghatározott tudásanyag, amivel közel tizenkét évig foglalkoznak, az érettségi vizsga sikeressége nem jelentik azt, hogy az iskolák ahogy az egyetemek sem - képesek a diákokat úgy az egyetemre küldeni, hogy az általános műveltség és ismeretanyag minden részterülete lefedve legyen. „A pedagógusok alapképzése, legyen az bármenynyire is jó minőségű, tanulási eredményekre irányuló, és nem képes a gyakorlat minden részterületét sikeresen ellátni képes pedagógusokat kibocsátani. A szaktárgyi és a pedagógusmesterségbeli felkészítés terjedelme olyan mértékben bővült, hogy mindez nem szorítható be az alapképzés keretei közé. Az egyes iskolák, területek közötti eltérések sajátos kompetenciákat igényelnek, amelyre a speciális felkészítés csak a munkahely ismeretében, továbbképzési formában oldható meg." (Falus, 2013, 22. o.). A pedagógusok körében a sikeresség érdekében kiemelendő az élethosszig tartó tanulás kulcsszerepe is.

Az általános iskolás korosztályt szemlélve már hat-hét éveseknél megfigyelhető például néptánc próbákon, fellépéseken, zenei tanulmányokban és iskolai versmondó versenyeken a megkövetelt színpadi fegyelem: tehát az ember korához és 
tevékenységéhez illő, számonkérhető előadói magatartás. A fegyelmezettség kifejezésének használata jelentőséggel bír, tudnillik a nyilvánosság előtti előadás- és megjelenésmód, kiállás, beszédtechnikai gyakorlottság már az óvodai szocializációs, kulturális tevékenységekben is ismert különböző ünnepek közös megélésének alkalmával. Ezek a szereplési lehetőségek az oktatási intézmények különböző projektnapok szervezésében is megjelenik, például a műsorra való készülődés munkafolyamatában, beleértve az óvodákban a szülő-gyermek- pedagógus kapcsolatának közös tevékenységét is. Ez az életre, élethelyzetekre nevelés folyamata: „A múvészi tevékenység mind a mai napig megőrizte beavatás jellegét: a műalkotások által közvetített sors- és magatartásminták megismerése az egyén szocializációjának döntő mozzanata, a kulturális közösség fennmaradásának biztosítéka." (110/2012. Korm. rendelet, 10784. o.). A drámapedagógia mint művészi tevékenység, segítséget nyújthat az egyetemi éveit, a gyakornoki idejét vagy az első munkanapját kezdő pedagógusjelöltnek, tanárnak is. A drámás módszertan lehetőséget nyújt a pedagógus pályára készülők személyiségének fejlesztésére is, elvégre a tanítási gyakorlatok ideje alatt gyakran kerül a tanárszakos hallgató abba a kettős szerepe, hogy a nap egyik felében diák, a másikban pedig tanárként kell helytállnia. Egyszerre ülnek még az egyetem padjaiban, és kezdenek oktatni a gyakorló iskolákban. Ezzel párhuzamosan jelenik meg a szerepváltás, a szerepbizonytalanság problémája is. (Bikics, 2013). A szakmai tudás gyakorlatba való átültetése, az osztályok előtti megszólalás okozta stressz, és a mentor előtti megfelelni akarás vágya túl sok figyelemmegosztást igényel ilyenkor a gyakorló pedagógustól.

A dráma eszköztára ,szinte nélkülözhetetlen a személyiségfejlesztésben, a pedagógus alkalmasság érdekében. A drámás készség- és képességfejlesztés, kommunikációs tréningek, helyzetgyakorlatok, szituációs játékok a tanári kompetenciafejlesztés talán leghasznosabb eszközei lehetnének. Emellett igen fontos alkalmazása a szakmódszertani fejlesztésben (pl.: hospitálások drámaórákon és drámás módszertannal dolgozó nem-drámaórákon, előadások, workshopok, meghatározott tantárgyi célú foglalkozások stb.). Maguk a hallgatók, a tanítási gyakorlatukat végző tanárjelöltek fogalmazzák meg a legpontosabban, milyen sokat segítenek ezek a tevékenységek személyes módszertanuk kialakításában.” (Eck, 2016, 111. o.). A tanári szerepbe lépés a drámapedagógia segítségével már a gyakorlatot megelőzően is létrejöhet, és nem a mikrotanításokhoz hasonló környezetben, sőt az ott történő megmérettetéseket is előkészítve. Amíg a mikrotanítások alkalmával a pedagógusjelölt már saját tanári megnyilvánulásait ízlelgeti a hallgatótársak körében, addig egy kezdő drámás csoportban különböző tanári szerepeket ölthet magára. Ezt megteheti úgy, hogy közben nem önmagát kell játszania, hanem egy- 
egy tanártípust, szerepet, mely segíthet abban is, hogy elkezdje kialakítani saját pedagógiáját.

A végzett pedagógusok körében megjelenő korai pályaelhagyások egyik oka lehet az ún. „start-sokk”. A kifejezést a Bielefeldi Egyetemen végzett kutatásban résztvevők fogalmazták meg a különböző intézményekbe, élethelyzetekbe történő átlépésekkel kapcsolatban végzett vizsgálatuk során. A „start-sokk” arra az átmeneti állapotra utal, amit az iskolából az egyetemre, az egyetemről a munkaerôpiacra való átlépés okoz. A kezdő, végzős és már végzett hallgatók körében végzett kutatásban arra jutottak, hogy az ún. „startsokk" mind a két (iskola-egyetem, egyetem-munkaerőpiac) átlépés esetében érezhető. Az is vizsgálták a projektben, hogy milyen képességeket kellene fejleszteni, hogy ezen az átmeneti állapoton sikeresen túl lehessen jutni. Ezek a rugalmasság, alkalmazkodó- rendszerező és problémamegoldó képesség, felelősségvállalás, kockázatvállalás és önérvényesítés. (Bikics, 2013). A kutatásban elemzett terület azt s mutatja, hogy a szakmai fejlödés folyamatos, de élethelyzethez mérten változatos.

A Magyarországon szakmai gyakorlatukat teljesítő hallgatók, vagy pályakezdő éveiket kezdő pedagógusok - ha már csak Budapestre és környékére gondolunk olyan iskolába is betérhetnek, és olyan diákokkal is találkozhatnak, akik az élet valamilyen területén, de főként a szociális pilléren sérültek. Többen ezek közül a ta- nulók közül nem rendelkeznek olyan mintákkal, tanulási és életvezetési módszerekkel, amik a mindennapi nehézségekben segíthetnének nekik. Az a belső elszigeteltség, amit az említett ingerek ellen építünk, nem biztos, hogy egyedül lerombolhatók. Nélkülözhetetlen az, hogy az oktatási intézményekben dolgozók rendelkezzenek olyan tudással, tapasztalattal és gyakorlattal, amivel - egy bizonyos szakmai szintig - segíteni tudják a felnövekvő nemzedéket. A dráma lehet egy prevenciós eszköz is, amivel a kapcsolatok, a segítségadás felé nyitjuk ki a kapunkat (VargaCsikász, 2018).

Felmerül a kérdés azonban, hogy a drámapedagógiának milyen személyiségfejlesztő, motiváló hatásai lehetnek a pályakezdő és már kisebb tapasztalattal rendelkezdő pedagógusok munkájára, életére, és ezt hogyan lehetne vizsgálni. Az oktatás körforgásába ugyanis csak általuk kerülhet be a módszer sokszínúsége.

\section{A DRÁMAPEDAGÓGIA PEDAGÓGUST FEJLESZTŐ HATÁSA}

„A jó drámatanár olvasott, és nemcsak szakmailag az (drámakönyvek, újságok és cikkek iránt érdeklődve), hanem építhet a jó irodalom széles körű ismeretére. Ez utóbbiba - saját kedvencei mellett - bele kell, hogy tartozzanak a gyermek- és ifjúsági regények, novellák, a mítoszok, legendák, tündér- és népmesék, mindenfajta vallás »bibliai« történetei, s az emberiség 
története, pozitív és negatív hőseivel együtt. Az is fontos, hogy ismerje a kortárs irodalmat, a tévé- és mozifilmeket, újságokat, képregényeket olvasson, kiállításokat nézzen, hogy kiismerje magát a világban és iskolán kívüli szûkebb környezetében. Ez a háttér minden tanár esetében kívánatos, azonban a drámatanárnak elengedhetetlen, mert a felsoroltak a tanórai-osztálytermi ötletek forrásai lehetnek. (Morgan-Saxton, 1989, In: Lipták Ildikó 2006.)" (Körömi, 2016, 163. o.). A felsorolt ismeretek a drámatanárok, drámapedagógusok mellett szakmai táplálékot nyújthatnak bármely pedagógusnak. Ebben az eltérő korosztályok érdeklődésének és befogadóképességének ismerete elengedhetetlen bizonyul, főleg ha bármely szakmabeli hatékonyan szeretné végezni a munkáját - legyen szó a bölcsödétől a felnőttképzésig.

Egy frissen végzett pedagógus hallgató életében mérföldkőnek számít a diploma megszerzése és az utána elkövetkezendő időszak is változásokkal teli - nemcsak szakmailag mérettetik meg, hanem az élet más területein is. $\mathrm{Ha}$ a diplomaszerzés időszakát követően rögtön állást kap egy kezdő tanár, és munkába is áll, még gyakran adódhatnak tapasztalatlanságából származó bizonytalanságai. Ha a friss diplomás tanár ebben az időszakban részt venne egy drámapedagógiai képzésen, láthatná, érezhetné, tapasztalhatná magán a pozitív változásokat. Például a drámás gyakorlatok által magabiztosabbá válna az előadásmódjában, az osztálytermi környe- zetben történő bizalomteljes légkör kialakításában - tehát fejlődne a különböző tanári kompetenciáiban (Hivatal, 2020). A drámapedagógia segítségével - ha maga a pedagógus résztvevőként van jelen pályakezdőként megélt frusztrációik oldottabbá válhatnak. „Szerepjátékról akkor beszélünk, ha valaki egy másik személy szerepét vagy funkcióit játssza el. Például ha az előbb leírt mikrotanítási szituációban az iskolásokat egyetemisták helyettesítik, már nem szimulációról, hanem szerepjátékról van szó.” (Falus, 2007, 242. o.). A fejlődési terület függ a drámás képzés tematikájától, céljától is, de a mások által tartott szabályjátékok, adaptációk és a vizsgákra összeállított számtalan tanítási drámán való részvétel egy kötetlenebb mikrotanítási gyakorlatként is értelmezhetô.

„Keveset tudunk a jelenleg létező színházpedagógiai gyakorlatok közvetett és közvetlen oktató-nevelő hatásairól, illetve arról, hogy az iskolák milyen arányban és milyen hatékonysággal tanítják a tantárgyat.” (Kaposi, 2015, 2. o.). A már többször említett 2015-os kutatás, melyet Szabó Zsófia nevével együtt olvashattunk egy olyan projekt része volt, melyre $\mathrm{Ka}$ posi József is utal. „A drámaoktatás helyzete a köznevelésben és a színházi nevelés a köznevelés eredményességéért" című pályázat egy projekt, a TÁMOP 3.1.15. részeként jöhetett létre. A Drámapedagógiai Magazin 52. számában Szabó Zsófia munkája mellett még számtalan írás született a dráma jelenlegi helyzetéről. Bethlen- 
falvy Ádámék szintén részt vettet pozitív eredményről beszámoló kutatásban, aminek beszámolója 2010-ben jelent meg.

A projektben tizenkét ország vett részt: Magyarország mint vezető, és további partnerekként Csehország, Egyesült Királyság, Hollandia, Lengyelország, Norvégia, Palesztina, Portugália, Románia, Svédország, Szerbia, és Szlovénia. (DICE Konzorcium, 2010). A beszámolóban összefoglalják azokat az eredményeket, melyek bizonyítják, hogy a drámás foglalkozásokon résztvevő diákokon milyen pozitív változásokat véltek felfedezni. Ezzel kapcsolatban felmerülhet az a kérdés, amiről már szót ejtettünk: milyen tanárrá válik az a személy, aki fiatalon találkozott, vett részt „drámás foglalkozásokon”? Dudás Margit szavait idézve olvashattuk már, hogy „az ilyen háttérrel rendelkező tanárjelöltek eredményesebben oldották meg a kapcsolatteremtési, kommunikációs képességek működését igénylő feladatokat (Dudás, 1984; Komlósi, T. Dudás, Vastagh, 1987).” (Dudás, 2013). A DICE Konzorcium hipotézisében megfogalmazta, hogy a tanítási színház és dráma a nyolc „Lisszaboni Kulcskompetencia” közül ötre lesz befolyással. Megállapíthatóvá vált, hogy a diákok, akik részt vettek a foglalkozásokon:

- „tanáraik értékelése szerint minden szempontból jobb teljesítményt nyújtanak;

- magabiztosabbak azokban a feladatokban, ahol olvasniuk kell, vagy meg kell érteniük valamit;
- magabiztosabban kommunikálnak;

- inkább tartják kreatívnak önmagukat;

- jobban szeretnek iskolába járni;

- nagyobb örömüket lelik az iskolai feladatokban;

- jobban oldják meg a problémákat;

- hatékonyabban küzdenek meg a stresszel;

- jobb a humorérzékük;

- jobban érzik magukat otthon" (DICE Konzorcium, 2010).

A huszonkettő vázlatpontból itt most tíz lett kiemelve, ámbár ezekből is kitűnik, hogy az iskolai tevékenységek és a személyiségjegyekre gyakorolt hatások mellett a diákok világhoz való viszonyulásában (például humorérzék) is felfedezhető a változás, de a kontrollcsoporton nem. „Mindannyian tudjuk, hogy a gyerekek tanulási folyamatának legnagyobb része a játékon keresztül valósul meg." (Mérei és V. Binét, 1997, 122. o.). Tehát a drámapedagógia által elért pozitívumok az iskolai kereteken is túlnyúltak: a résztvevők másokról és önmagukról alkotott képükre, a kapcsolatrendszereikre, hozzáállásukra, motivációjukra is befolyással bírt.

Az eredményeket szemlélve jogosan merülhetne fel bárkiben (gyerekben, szülőben, pedagógusban) az az igény, hogy ezeket a pozitívumokat a fiatal a felnőtté válás alatt és után is meg tudja őrizni, tovább tudja fejleszteni és adni. „A pedagógus a csoport és a csoportfejlődés pszichológiai, szociológiai, kulturális sajátosságainak ismeretében képes olyan pedagógiai helyzeteket teremteni, amelyek elő- 
segítik a tanulók szűkebb és tágabb közösségek iránti elkötelezettségét, amelyek alapján nyitottá válnak a demokratikus társadalomban való aktív részvételre, a helyi, a nemzeti és az egyetemes emberi értékek elfogadására. Képes a tanulói közösségeket tudatosan szervezni, a konfliktusok építő megoldását segíteni és előmozdítani az iskolai demokráciát." (Pedagóguskompetenciák és a Pedagógus I. szint sztenderdjei, 2. o.). A drámatanárról elmondható, hogy a teljes személyiségét áthatja a tárgyának eszmerendszere és nem tud kilépni belőle: megjelenik a nevelési módszereiben, a tanórán kívüli tevékenységében. A drámatanár még más szaktárgy oktatásában is a cselekvésre buzdító, aktivizáló eszközt részesíti előnyben. A „drámás” módszertan elsődleges szerepet tölt be a közösségi létben, a pedagógus iskolai cselekedeteit - pozitív értelemben - olyannyira átszőve, hogy nem tud kilépni a drámatanári szerepből. Ezt az aktivizáló tanári mintát minden pedagógusjelöltnek (reál- és humán szakon is) ismernie kellene, mert nem biztos, hogy találkozott vele.

\section{EGY LEHETSÉGES KUTATÁSI TERÜLET}

Kutatás cél lehet azt vizsgálni, hogy a drámapedagógia milyen pedagógiai, személyiségfejlődési hatással bírhat a gyakorló- vagy pályakezdő pedagógusokra, illet- ve, hogy ezek a hatások miben és hogyan nyilvánulnak meg.

E vizsgálat során a következő kérdésekre kereshetnénk, találhatnán válaszokat:

1. Napjainkban milyen nehézségekbe ütközi egy pályakezdő pedagógus és ebben milyen segítségére lehet a drámapedagógia módszere?

2. Fejlesztő hatással van-e a drámapedagógia módszere a tanári kompetenciák gyakorlására, és ha igen, hogyan?

3. Szükséges-e a drámapedagógiát beépíteni a felsőfokú pedagógusképzésbe?

Egy ilyen kutatás tehát elősorban a pályakezdő pedagógusokra vonatkozó hatásokat vizsgálná, amelyeknél kvalitatív és kvantitatív kutatási módszerek kerülnének előtérbe. A kutatási minta alapját a gyakorló és pályakezdő pedagógusok jelentenék, azok, akik nem találkoztak vele, érdeklődnek a módszer iránt és szeretnének megismerkedni a drámapedagógiával, vagy mélyíteni kívánják a témában szerzett ismereteiket. Egy korábbi vizsgálathoz (Varga-Csikász, 2018) alkotott kérdőívet tovább gondolva, módosítva azt, lehetne egy nagyobb létszámú csoporthoz eljuttatni, főként az új generációs pedagógusokra gyakorolt hatást vizsgálva.

Induktív módszerrel lehetne megközelíteni azt a kérdést, hogy a pedagógusok hogyan készülnek egy-egy drámapedagógiai foglalkozásra, akár rendelkeznek ebben nagyobb tapasztalattal, akár nem. Kutatási szempontból fontos lehet, hogy a rutin vagy annak hiánya hogyan hat a 
részvevőkre, illetve a játékvezetőre a dráma eszközeinek használata közben.

Az tervezett órákról hospitálási naplók is készíthetők, melyek tartalomelemezéssel vizsgálhatók és összehasonlíthatók az órára készített foglalkozás tervével. Az önreflexiókat a dokumentumelemzés módszerével lehetne feldolgozni.

A mérések alkalmával panelvizsgálatok is végezhetők, így további kutatás létrehozása is lehetséges annak érdekében, hogy adatokat kapjunk arról, milyen eltérések figyelhetők meg a tanári kompetenciákban a drámaképzés előtt és után.

A kutatás várhatóan alátámasztaná, hogy a drámapedagógiának meghatározóbb helye lehetne az oktatásban. A XXI. században a nevelési intézményeknek - a felnövekvő generációkat ért hatásokat fokozottan tanulmányozva és követve - a tárgyi tudás átadása mellett közösségépítő, személyiségfejlesztő módszerekre nagyobb hangsúlyt kell helyezniük : „Az iskola olyan értékrend kialakításához járul hozzá, amely megalapozza, hogy az egyén személyes boldogsága mellett értékesnek tekintse a társadalmi együttéléshez szükséges kötelezettségek teljesítését és a különböző társadalmi szerepek betöltését. A köznevelés célja és feladata az, hogy támogassa a fejlődő-kibontakozó egyént a harmonikus egyensúly megtalálásában..." (A Nemzeti alaptanterv tervezete, 2012, 1. o.). Az ember és technika viszonyába a technikát, mint eszközt kell megtartani, és a személyes jelenlétet áthidaló lehetőségei mellett a fiatalokat tudatosabb használatra nevelni vagy ösztönözni, mivel sokszor jobban értenek hozzá, mint az idősebb generációk. Ahhoz, hogy az iskola fő funkcióját betöltve az életre nevelje a gyerekeket, olyan pedagógustársadalom képzésére van szükség, akik - változó oktatási és techno-lógiai környezethez, tanulói sajátossá-gokhoz alkalmazkodva - személyiségük és jelenlétük mellett továbbra is mintaként szolgálnak az oktasi, tanulási eszközök használatában, közösségépítő tevékenységeik szervezésében, levezetésében.

\section{ZÁRÓGONDOLATOK}

A drámapedagógia, mint az általánosságban elmondható, bár nem alkalmazható mindig minden helyzetben és minden csoportban, de olyan közösségépítő, ventilálási, átélési, gondolkodtatási lehetőségeket kínál, melyeket minden pedagógusnak ismernie, alkalmaznia és terjesztenie kell. A módszert a gyerekek és önmaguk személyiségének színesítésére is használhatják. „Minden, ami a nyilvánosság előtt játszódik, olyan, mint a színház. Éppen ezért, akiket rövid időn belül a közéletbe küldenek, úgy neveljék, hogy ott megfelelően állják meg a helyüket, s a rájuk bízott feladatokat kellően végezzék el. (»Schola Ludus«, Sárospatak, 1656)" (Gabnai, 1999). A szerepek megfelelő alkalmazását, védő funkcióit, fel- és levételét, a szociális érzékenyítést pedig ugyanúgy tanítanunk kell, mint a tárgyi tudás megszerzését. 
A pedagógussá válással kapcsolatban már kitértünk a drámapedagógia jelentőségére. Ha a pedagógusjelöltnek a középiskolában nem adódott meg, hogy megélje ennek a módszernek a személyiségfejlesztő hatását, akkor az egyetemek - az újabb életszakaszok nehézségeire is válaszokat, feloldásokat keresve - fel kellene kínálniuk ezt a továbbképzési lehetőséget. A drámapedagógia az általános tanárképzésbe bekerülve az új szerepek megélésében, az új kapcsolatok kiépítésében, önreflexió elsajátításában kínálhat gyakorlatot. „Szükség van a kudarctűrő képesség fejlesztésére is, és nem csak a szakmaiintellektuális vonatkozásban. Hiszen a tanulmányok kezdete egyben a felnőtté válás kezdete a maga sajátos életfeladataival és csalódásaival, mint a próbálkozás és feladás, a partnerkapcsolat-teremtés és szakítás, a tervezés és kudarcba fulladás." (Bikics, 2013).

A fentebb felvetett kutatás tehát várhatóan adatokkal szolgáltahat arra, hogy a drámapedagógia a tanári kompetenciákra a pedagógusok gyakorlati és pályakezdő éveiben nagy jelentőséggel bír, ezért az új generációs pedagógusok oktatásában elengedhetetlen lesz a dráma eszközeinek használata, mert „,a dráma mint megközelítésmód »az oktatásban végbemenő kreatív forradalom« (Burges, 1986) egyik példája." (Szauder, 2013).

\section{IRODALOM}

110/2012. (VI. 4.) Korm. rendelet A Nemzeti alaptanterv kiadásáról, bevezetésérõl és alkalmazásáról

A Nemzeti alaptanterv tervezete (2018). Letöltés: 2020.04.30. Web: https://www. oktatas2030.hu/wp-content/uploads/ 2018/08/a-nemzeti-alaptanterv-terve zete_2018.08.31.pdf

Bethlenfalvy Á. (2017). Színházi nevelési programok - nemzetközi kitekintés. In Cziboly Á. (Szerk.): Szinházi nevelés és szinháapedagógiai kéziłoünyv (112-145. o.). InSite Drama. Letöltés dátuma: 2020. 04.29. Web: https://www.szinhazineveles.hu/wpcontent/uploads/2018/01/Szinped_P rog_Final_6.pdf

Bethlenfaly Á. (2005). Fejezetek az angol drámapedagógiai történetéből (2.). Drámapedagógiai Magazin, 16-23. Letöltés: 2020.04.30. Web: http:/ / epa.oszk.hu/03100/03124/000 40/pdf/EPA03124_dpm_2005_1_016 -023.pdf

Bikics G. (2013). Tanulóból tanárrá válni. Kihívások, nehézségek és segítségnyújtási lehetőségek a pedagógussá válás kezdetén. In Golnhofer E. és Kotschy B. (szerk.): Új utak a pedagóguskutatásban. EKF Líceum, Eger. 7-26.

Bolton, G. (1993). A tanitási dráma elmélete. Marczibányi Téri Művelődési Központ, Budapest.

Bolton, G. (1996). A tanítási dráma újragondolása. Drámapedagógiai Magazin Különsqám. Letöltés: 2020.04 29. Web: 
http://epa.oszk.hu/03100/03124/000 14/pdf/EPA03124_dpm_1996_k.pdf DICE Konzorcium. (2010). DICE - a kocka el van vetve, Kutatási eredmények és ajánlások a tanitási szinház és dráma alkalmazásával kapcsolatban. Letöltés: 2020.04.10. Web: http://www. dramanetwork.eu/file/DICE_kutatasi _eredmenyek.pdf

Dudás M. (2013). „Az iskola egy színház, és ebben a színházban a tanár a dramaturg...”. In Golnhofer E. ésB. Kotschy B. (szerk.): Új utak a pedagóguskutatásban. EKF Líceum, Eger. 5571.

Eck J., Takács G. és Neudold, J. (Előadók). (2019. 11 19). Kinyílt az aranykapu? Szinházi nevelés és a rendszerváltás. Revizor OFFline, Magvető Café, Budapest.

Eck J. (2015). A dráma helye a közoktatásban. Drámapedagógiai Magaẓin, 5-7. Letöltés: 2020.04.30. Web: http:/ /letoltes.drama.hu/DPM/20152017/2015.2.pdf

Eck J. (2016). A dráma helye a közoktatásban és a tanárképzésben. In K. Illés (Szerk.): Dráma, pedagógia, szinháą, nevelés: szöveggyüjtemény köréphaladóknak. Budapest: OFI. 91-113. Letöltés: 2020.04.10. Web: http://ofi.hu/sites/ default/files/attachments/dramapeda gogia_online.pdf

Falus I. (Szerk.). (2007). Didaktika - Elméleti alapok a tanitás tanulásához. Nemzeti Tankönyvkiadó, Budapest.

Falus I. (2013). Új tendenciák a tanártovábbképzés nemzetközi. In Falus I.
(Szerk.): Pedagógus-továbbképzés, Nemzetközi áttekintés. Líceum Kiadó, Eger.

Gabnai K. (1999). Drámajátékok - Bevezetés a drámapedagógiába. Helikon Kiadó, Szekszárd.

Habos D. (2018). A pedagógus tanórai és órán kivüli tevékenysége a digitális kompetencia és a mediatudatosságra nevelés tükéében. Kutatási terv. Eszterházy Károly Egyetem Neveléstudományi Doktori Iskola.

Heathcote, D. (2013). A konvenciókról. In Kaposi L. (Szerk.): Drámapedagógiai olvasókönyv. II. Kerületi Kultúrális Közhasznú Nonprofit Kft. Marczibányi Téri Művelődési Központ, Budapest. 123-125-

Pedagóguskompetenciák és a Pedagógus I. squint sztenderdjei. Oktatási Hivatal, Budapest. Letöltés: 2020.04.30. Web: https://www.oktatas.hu/pub_ bin/dload/pem/Pedagogus_I_sztende rdek.pdf

Hull, S. (1999). Szinészmesterség mindenkinek. Tericum Kiadó Kft., Budapest.

Kaposi J. (2015). Bevezető. Drámapedagógiai Magaz̨in, 2. Letöltés: 2020.04.30. Web: http://epa.oszk.hu/03100/ 03124/00081/pdf/EPA03124_dpm_2 015_2.pdf

Körömi G. (2016). Drámapedagógusok az oktatásban. In Illés K. (Szerk.): Dráma, pedagógia, színház, nevelés: szöveggyüjtemény középhaladóknak. Oktatáskutató és Fejlesztő Intézet, Budapest. 159-178. Letöltés: 2020.04.30. Web: https:// 
ofi.oh.gov.hu/sites/default/files/attac hments/dramapedagogia_online.pdf

Magyar Drámapedagógiai Társaság. Letöltés: 2020.04.29. Web: https://drama. hu/magyar-dramapedagogiai-tarsasag/ Mérei F. és V. Binét Á. (1997). Gyermeklélektan. Medicina, Budapest..

Neelands, J. (2013). A drámát érintő alapvető gondolatok. In Kaposi L. (Szerk.): Drámapedagógiai olvasókönyv. II. Kerületi Kultúrális Közhasznú Nonprofit Kft. Marczibányi Téri Művelődési Központ, Budapest. 8-10.

Papp G. és Trencsényi L. (szerk.)(1984). Szinjátszás - dramatikus nevelési program 1972-1982. Népművelődési Intézet, Budapest.

Pukánszky B. és Németh A. (1996). Neveléstörténet. Nemzeti Tankönyvkiadó, Budapest.

Szabó Z. (2016). Drámapedagógia a köznevelés információs rendszerében. statisztikai adatok tükrében. In Illés K. (Szerk.): Dráma, pedagógia, szinház, nevelés: szöveggyüjtemény középhaladóknak. Oktatáskutató és Fejlesztő Intézet, Budapest. 65-90. Letöltés: 2020. 03.20. Web: http://ofi.hu/sites/default/files /attachments/dramapedagogia_online .pdf

Szauder E. (2013). A dráma mint pedagógia. In Kaposi L. (Szerk.): Drámapedagógiai olvasókönyv. Magyar Drámapedagógiai Társaság, Marczibányi Téri Müvelődési Központ, Budapest. 11-26.

Szőke-Milinte E. (2019). A Z generáció megismerése - megismerés a $Z$ generációban. In J. Kaposi J. és. SzőkeMilinte E. (szerk.): Pedagógiai változások - a változások pedagógiája. Pázmány Péter Katolikus Egyetem. Budapest. 130144. Letöltés: 2020.04.29. Web: http://btk.ppke.hu/uploads/articles/ 1734918/file/Pedag\%C3\%B3giai $\% 20$ v\%C3\%A1ltoz $\%$ C3\%A1sok $\% 20 \mathrm{~B} 1 \%$ 2BB4\%2Bbel $\%$ C3\%ADv $\% 20$ screen.p df

Tölgyessy Zs. (2011). A drámapedagógiai jelenléte a Vág-Duna-Ipoly eurorégió irodalomóráin. ELTE, Budapest. Letöltés: 2020.04.29. Web: https:// ppk.elte.hu/file/tolgyessy-zsuzsanna_ dissz.pdf

Varga-Csikász, Cs. (2018). A drámapedagógia jelene a mai magyar oktatásban. Szakdolgozat, Pázmány Pétet Katolikus Egyetem, Piliscsaba. 